\title{
En Afstaaelses- og Præsteenkepensions-Kontrakt af Marts 1705.
}

\section{V'ed Erh. Qvistgaard.}

Følgende Kontrakt blev oprettet i Marts 1705 mellem Sognepræst i Daler, Egidius Hansen Gram og Studiosus Andreas Wedel, som han antog som sin Capellan; den blev fornyet d. 9. Aug. 1707 ved Skiftet efter førstnævnte og endnu engang fornyet i 1709 d. 28. Maj. Alligevel overholdt $\mathrm{Hr}$. Wedel trods venlig Erindring ikke Kontrakten overfor Præsteenken, som var hans Svigermoder, sikkert ikke af ond Vilje, men, som han selv siger, "for Kaldets Ringheds Skyld«. Da han saaledes ikke kunde overholde den, indsendte han 1720 en Klage til Kongen, der henviste Sagen til Lands Lov og Ret. I den Anledning afholdtes der Provsteret i Møgeltønder Kirke d. 10. Dec. 1720 og flere Gange senere til Ordning af denne Sag, der endelig blev forligt.*)

Da det kan have sin Interesse at lære denne Kontrakt at kende, fremsattes den her saalydende:

Udi den naadige hel. Trefoldigheds Navn!

Saa som jeg underskrevne p. t. Sognepræst her til Daler Menighed er bleven foraarsaget en Medhjælper i Embedet til mig at antage og vores naadigste høje Øvrighed og Patron her paa Stedet dertil beskikket og mig tilforordnet vellærde Studiosum Andreas Wedel med hannem for bedre Rigtigheds skyld følgende Afskeed og Contrakt i saa Maader sluttet og indgangen.

1. Forbliver ieg self, saalænge Jeg lever, Hoved og Pastor for Kaldet, velermelte min tilkommende Medhjælper Adjunktus Pastor, indtil han mig efter min Død succederer.

2. I Henseende dernast herved til vor Huses Conservation

*) Hendes Sag fortes for Provsteretten af en anden af hendes svigersønner, Raadmand Peter Giese i Tønder. 
samt og nærmere Venskab at stifte saasom Andreas Wedel Huseț Affection høfligen søgt, da efter Guds forsiun et kærligt Egteløfte er sluttet mellem ham og vor ældste kære Datter Anna Cathrina, hvortil Gud give Lykke og V'elsignelse.

3. Præstegaarden, bestaaende in alles udi $68 \mathrm{fag}$ med Salsog Ladehuse og hvad Navn det have kand betaler Andreas Wedel og annammer efter indbyrdes venlig forening for den Summa 700 Sl. dl. siger Syv Hundrede Slette Daler, hvorimod efter min Død de andre 2 Søstre Anna og Anna-Margrethe skal forlods af mine efterladte Midler og Bohave ske fuld Vederlag og fornøjelse.

4. Vi Forældre, saa længe vi leve, staa for Avling og Husholdning og imidlertid svare til de expenser som til Præstegaarden vedlige at holde, kgl. Skatter, samt hvis andre Udgifter dagligen ved Oekonomien plejer at forefalde. De unge Folk saa længe leve med os in communi eller fællig, Andreas Wedel imidlertid gør Tjeneste og Medhjælp og nyder af Kaldets Indkomst fra den Tid han Praedikeembedet betræder, saa længe han er ene og ugift, 50 Sld., siger halftresindstyve Slette Daler. Men naar han og min Datter komme i Egteskab, den 3. Deel af alt Kaldets Indkomst og imidlertid beholde til Husvarelse de to Nør-Kamre, hvilke min Hustru ligeledes efter min Død skal nyde til sine Husværelser.

5. Naar Gud efter sin naadige Villie giør Skilsmisse og een af os forældre bortkalder, afstaas og overlades Huusholdningen og Avlingen til vores tilkommende Svigerson og Daatter. Min Hustru til Ophold hendes Livstid nyder til Pension og Afgift aarlig efterfølgende: Udi reent Korn 5 Tønder Rug, 5 Tønder Malt, 2 Tønder Frem-Byg til Gryn, af de 3 Ofre om Aaret af hver 4 Rigsdl., som er 12 Rigsdl., af Smørbyrd 2 Ottendedele og Koe at holde hende paa Græs og Foder, hvormed saaledis skal forholdes, at ald den Stund min Hustru holder sin egen Kost naa hun aarlig hver Valborgs Dag og hver Allehelgensdag udvælge paa hans Stald, hvilken Koe hende selv behager; 1 feed Svin og $\&$ feede Giæs. 4 Rdl. til et Slagte-Nød, Vinterfoder til \& 
Faar, 6 Læs Klyne Tørv og 8 Læs Brænde. Alt dette foreskrevne lover jeg Andreas Wedel til velermelte Marina Fr. Egidii udi rette Tide aarlig at levere og tilkomme lade. Men skulde det saa paa begge Sider behage paa Kosten og Husholdningen hos os at blive, da modereres Pensionen dog saa vidt, at Kornet af Rug og Malt samt og det Kvantum af Penge i Offeret bliver ved Magt, at hun det aarlig haver at nyde til anden Fremtarv, det andet at falde og efterlades. Skulde $\mathrm{i}$ det ovrige Tiderne sig forandre og Tilstanden saaledes, at Marine, Hr. Egidii blev til Sinds udi Tonder eller andet Sted sig at nedscette, skal hende den foreskrevne Aftægt did rigtig leveres hvert Aar, saalænge hun lever uden hvis som bekvemlig ikke tilfores kan, saasom foderet og Brændsel, derfor hende udi Penge at fornøje efter Billighed og desforuden 4 Rdl. til Hjalp til Husleje samme steds aarlig.

6. Skulde det endelig efter Guds Vilje vare, at Jeg Hr. Egidius min Hustru skulde efterleve, da mig foruden Kosten, den halve Deel af Kaldets Indkomster visse og uvisse at tilkomme, saa længe det da kunde være. Dette, som nu saaledes venligen mellem os aftalt og forskrevet er, oprigtelig og ubrodelig i alle sine Punkter af os skulle holdes og efterleves uden ringeste Fxception og Indvending have vi med vore egne Hænder i denne Contrakt underskrevet og vore sædvanlige Signeter hos trøkt venligen og ombedet Velarværdige, meget haderlige og vellærde Mand Hr. Daniel Blechingberg og Hr. Peder AEgidii nahler med os til Vitterlighed som overværende at underskrive og forsegle. Og eftersom behorig Papir ikke nu var ved Haanden love vi nærværende Contrakt, naar Behov giøres og begæres derpaa beskreven at give.

Actum Daler Præstegaard, Martii 1705.

Denne Kontrakt blev i alt væsentligt fornyet mellem $\mathrm{Hr}$. And. Wedel og hans Svigermoder d. 28. Maj 1709. Dog lover han nu ogsaa at forskaffe sin kære Svigermoder en hæderlig Begravelse til Gengæld for noget, hun eftergav ham, og slutter den med disse Ord: "Og skal hermed al Stridighed mellem os gan- 
ske og aldeles være ophævet og vi saaledes med hinanden os herefter forholder som det kan være Gud og vore gode Venner til Glæde og Velbehagelighed og os selv til en god Samvittighed."

(Deres Underskrifter.)

Trods dette højtidelige Løfte har der sikkert stadig været Coverensstemmelser for ikke at sige Strid mellem dem, thi $\dot{i}$ Aaret 1713 maatte Biskop Oksen i Ribe igen forlige dem paa omtrent de samme Vilkaar som tidligere og slutter Forliget med samme højtidelige Forsikring om at behandle hinanden med al christelig og svogerlig Kærlighed og Arvillighed i Fremtiden.

Da Provst And. Wedel fremdeles ikke overholdt Kontrakten og hans Gæld til Enken voxede, kom Sagen efter Kongens Befaling paa Grund af gensidig Klage herover for Provsteretten 1720, som foran nævnt, og blev endelig forligt saaledes, at Provst Wedel blev dømt til foruden Sagens Omkostninger at betale sin Svigermoder ialt 1530 Rdl., hvortil hans Gæld igennem Aarene efterhaanden var løbet op foruden enkelte mindre Ydelser.

Igen denne Gang blev Sagen forligt.

Hermed synes denne pinlige Strid endelig at være kommet ud af Verden, der høres i al Fald ikke mere til den, men om al Strid derfor mellem dem er endt, er et Spørgsmaal. 